\title{
MAKALAH PENJASORKES
}

$\mathrm{D}$

I

$\mathrm{S}$

$\mathrm{U}$

S

U

$\mathrm{N}$

Oleh : Cristian Totti Roniasi Pangaribuan

Kelas : X MIA 3

SMA NEGERI 3 MEDAN

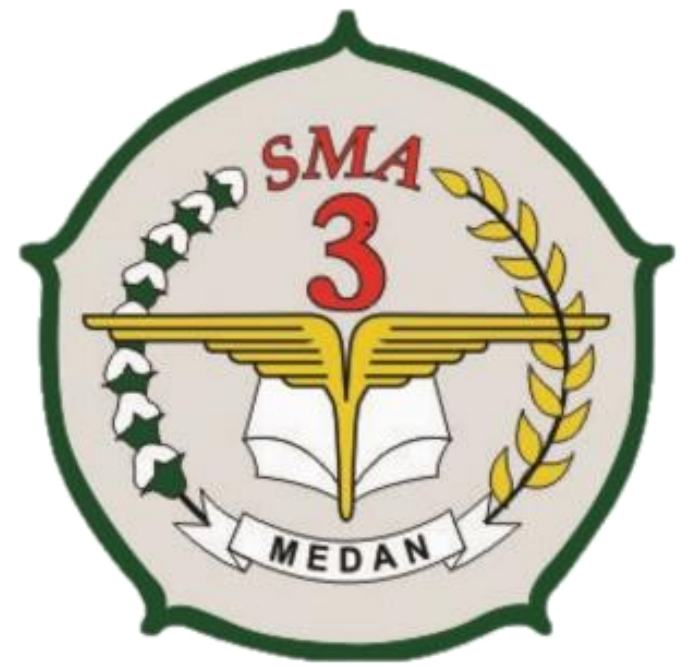




\title{
Efektivitas Pengajaran Lompat Tinggi Gaya Gunting (Scissors) bagi Siswa di Indonesia \\ Cristian Totti Roniasi Pangaribuan \\ X MIA - 3
}

\begin{abstract}
Abstrak
Efektivitas ini mengacu pada kemahiran para peminat lompat tinggi bagi pelajar di Indonesia, sehingga dapat membanggakan sekolah, kabupaten, kota, provinsi,bahkan Negara. Kita dapat lihat saat ini, dinegara seperti olahraga dalam kategori atletik ini popular dan banyak menghasilkan bibit-bibit unggul di negera itu, para siswa pun banyak yang menjadi mahir dalam melakukan lompat tinggi di sana. Banyaknya bibit-bibit muda juga didukung oleh banyaknya kompetisi dan banyaknya pusat latihan serta pelatih yang bagus. Pengajaran dilakukan oleh pelatih professional dan seharusnya menyebar di seluruh daerah Indonesia dan kompetisi atau event yang mendukung lompat tinggi ini.
\end{abstract}

Kata Kunci : Lompat tinggi, kompetisi, pelatih professional

\section{The Effectiveness of Teaching High Jump by Scissors Style to Students in Indonesia}

\begin{abstract}
The effectiveness refers to the proficiency of interested people in Indonesia, where schools, districts, cities, provinces, and even countries can be boasted. We can see today, in countries such as sports in this category, popular and producing good seedlings in the country, many students have become proficient at high jumping there. Many young seeds are also supported by competition and good training centers and coaches. Teaching is done by professional trainers and should be spread across Indonesia and the competition or event that supports the high jump.
\end{abstract}

Keywords: high jump, competition, professional coach 


\section{Pendahuluan}

Pendidikan jasmani merupakan pendidikan yang diberikan dalam satu mata pelajaran yaitu mata pelajaran Pendidikan Jasmani Olahraga dan Kesehatan (PJOK). Tujuan PJOK tidak dapat dilepaskan dari tujuan pendidikan nasional. Undang-Undang Nomor 20 Tahun 2003 tentang Sistem Pendidikan Nasional, Pasal 3, tujuan pendidikan nasional adalah mengembangkan potensi peserta didik agar menjadi manusia yang beriman dan bertakwa kepada Tuhan Yang Maha Esa, berakhlak mulia, sehat, berilmu, cakap, kreatif, mandiri, dan menjadi warga negara yang demokratis serta bertanggung jawab.

Pendidikan jasmani mengandung makna pendidikan yang menggunakan aktivitas jasmani untuk menghasilkan peningkatan secara menyeluruh terhadap kualitas fisik, mental, dan emosional peserta didik. Kata aktivitas jasmani mengandung makna bahwa pembelajaran berbasis aktivitas fisik. Kata olahraga mengandung makna aktivitas jasmani yang dilakukan dengan tujuan untuk memelihara kesehatan dan memperkuat otot-otot tubuh. Kegiatan ini dapat dilakukan sebagai kegiatan yang menghibur, menyenangkan atau juga dilakukan dengan tujuan untuk meningkatkan prestasi.

Pembelajaran PJOK memerlukan sarana dan prasana untuk mencapai tujuan pembelajaran, sehingga tercapai tujuan pembelajaran PJOK secara aman, efektif, dan efisien. Penyediaan sumber daya fisik yang memadai termasuk fasilitas, peralatan, dan pemeliharaan dapat membantu dalam memengaruhi sikap dan menunjang keberhasilan program. Dalam pembelajaran PJOK, fasilitas yang harus tersedia bagi peserta didik yang terlibat dalam aktivitas otot besar yaitu fasilitas untuk lari, melompat, menendang, melempar, menangkap, dan memanjat.

Materi yang diajarkan dalam PJOK terdiri atas olahraga permainan dan olahraga atletik, namun jenis olahraga atletik kurang diminati siswa. Atletik merupakan salah satu cabang olahraga yang memiliki banyak nomor dalam suatu perlombaan.

Dalam dunia olahraga, dikenal banyak sekali cabang olahraga, antara lain adalah atletik, permainan, senam dan beladiri. Dari keempat cabang olahraga tersebut, atletik mempunyai peranan penting, karena gerakan-gerakannya merupakan gerakan dasar bagi cabang olahraga lainnya. Atletik menurut Aip Syarifuddin (1992:2) berasal dari bahasa 
Yunani, yaitu Athlon yang artinya pertandingan, perlombaan, pergulatan atau perjuangan, sedangkan orang yang melakukannya dinamakan Athleta (Atlet). Dengan demikian dapatlah dikemukakan, bahwa atetik adalah salah satu cabang yang dipertandingkan atau diperlombakan yang meliputi atas nomor-nomor jalan, lari, lompat dan lempar.

Atletik merupakan dasar untuk melakukan bentuk-bentuk gerakan yang terdapat didalam cabang olahraga yang lainnya. Dengan mengikuti kegiatan latihan atletik, akan dapat diperoleh berbagai pengalaman yang sangat berguna dan bermanfaat bagi kehidupan, karena didalam melakukan kegiatan atletik akan dilatih kekuatan, kecepatan, kelentukan, kelincahan, ketepatan, daya tekan, koordinasi gerak, keuletan, kedisiplinan dan percaya diri serta bertanggung jawab (Aip Syarifuddin dan Muhadi, 1992/1993 : 60).

Kemampuan siswa dalam atletik terlihat dari kelincahan, kelenturan, gaya, dan teknik lompat jauh yang diterapkan. Penilaian meliputi tiga aspek utama yaitu pengetahuan, afektif (sikap dan perilaku), dan psikomotor (keterampilan motorik dan kebugaran). Beberapa teknik untuk melakukan penilaian adalah pengamatan, tes tulis, tes unjuk gerak.

Lompat tinggi merupakan salah satu bagian dari cabang olahraga atletik. Lompat tinggi adalah salah satu keterampilan untuk melewati mistar yang dipasang di kedua tiang. Tujuan dari lompat tinggi adalah mendapatkan lompatan yang setinggi mungkin. Ketinggian lompatan yang dicapai oleh pelompat ditentukan oleh kemampuan dan persiapan bertanding dari masing-masing pelompat. Hingga saat ini, ada empat gaya yang dikenal dalam lompat tinggi, diantaranya adalah gaya guling (Straddle) yang merupakan gaya dimana ketika badan melewati mistar dengan cepat diputar dan dibalikkan, sehingga sikap badan di atas mistar telungkup.

Lompat tinggi buat kesehatan adalah info yang menarik, tetapi sedikit didapati dalam warga. Info tentang lompat tinggi ini amat sedikit, serta seringkali dipandang cuma semacam olahraga yang bisa sehatkan badan. Tentu saja manfaatnya untuk kesehatan terdapat beberapa macamnya serta menarik untuk dipelajari oleh siapa saja. Manfaat lompat tinggi ini bisa anda nikmati bila anda seringkali lakukan lompat tinggi jadi 
olahraga anda. Di bawah ini beberapa manfaat jika ada lakukan lompat tinggi untuk kesehatan anda serta keterangan detailnya.

Dalam kehidupan modern, manusia tidak dapat dipisahkan dari olahraga, baik sebagai media adu prestasi maupun sebagai kebutuhan untuk menjaga kondisi tubuh agar tetap sehat. Olahraga mempunyai peranan penting dalam kehidupan manusia. Melalui olahragalah manusia dapat dibentuk menjadi sehat jasmani dan rohani, serta mempunyai kepribadian, disiplin, dan sportivitas yang tinggi sehingga pada akhirnya akan terbentuk manusia yang berkualitas.

Peningkatan efektivitas sering kali mendapat permasalahan yang tapi memiliki manfaat yang sangat besar. Jika di Indonesia ingin melakukan efektivitas ini, harusnya setiap sarana dan prasarana harus lengkap, banyak, dan terawat agar punya berbagai prestasi yang mempuni baik di tingkat nasional, regional, dan Internasional sekali pun. Kita lihat bagaimana olahraga ini di Amerika sangat banyak yang meminati bahkan anak-anak umur 5-12 tahun banyak yang telah masuk pelatihan yang dibimbing oleh pelatih professional dan berpengalaman, para orangtua juga turut andil dalam meningkatkan bakat dan kemampuan anak sehingga sang anak mendapatkan prestasi. Orang tua memberi kebebasan anaknya dalam mengembangkan bakat baik dalam olahraga, teknologi dan lainnya.

Terdapat sejumlah permasalahan yang dapat diidentifikasi, yaitu: (1) prestasi lompat jauh masih kurang, (2) sarana belajar masih kurang, (3) teknik-teknik lompat jauh tidak banyak dikenali siswa, (4) gaya jongkok dalam lompat jauh tidak banyak diajarkan, (5) kesempatan siswa untuk mencoba berbagai teknik kurang dimanfaatkan oleh siswa 


\section{Pembahasan Lompat Tinggi}

Lompat tinggi adalah olahraga yang menguji ketrampilan melompat melewati tiang mistar. Lompat tinggi merupakan salah satu bagian dari cabang olahraga atletik. Tujuan lompat tinggi adalah untuk memperoleh lompatan setinggi-tingginya saat melewati mistar tersebut dengan ketinggian tertentu. Tinggi tiang mistar yang harus dilewati pelompat minimal 2,5 meter, sedangkan panjang mistar minimal 3,15 meter. Lompat tinggi dilakukan di arena lapangan atletik dan tanpa bantun alat. Lompat tinggi termasuk dalam cabang olahraga atletik. Menurut Aip Syarifuddin, atletik berasal dari bahasa Yunani, Athlon, yang artinya pertandingan, perlombaan, pergulatan, atau perjuangan. Dengan demikian dapat diartikan bahwa cabang olahraga meliputi nomor-nomor jalan, lari, lompat, dan lempar. Atletik merupakan dasar untuk melakukan bentukbentuk gerakan yang terdapat di dalam cabang olahraga lainnya. Dengan mengikuti olahraga atletik, akan diperoleh berbagai pengalaman yang sangat berguna dan bermanfaat bagi kehidupan karena melatih kekuatan, kecepatan, kelentukan, kelincahan, ketepatan, daya tekan, koordinasi gerak, keuletan, kedisiplinan, dan percaya diri, serta bertanggung jawab.

Dalam pertandingan, mistar akan dinaikkan setelah peserta berhasil melewati ketinggian mistar. Peserta mestilah melonjak dengan sebelah kaki Peserta boleh mulai melompat di mana-mana ketinggian permulaan yang disukainya Sesuatu lompatan akan dikira batal jika peserta menyentuh palang dan tidak melompat. Menjatuhkan palang semasa membuat lompatan atau menyentuh kawasan mendarat apabila tidak berjaya melompat Peserta yang gagal melompat melintasi palang sebanyak tiga kali bertutrut-turut (tanpa di ambil kira di aras mana kegagalan itu berlaku) akan terkeluar daripada pertandinga Seseorang peserta berhak meneruskan lompatan (walaupun semua peserta lain gagal) sehingga dia tidak dapat menuruskannya lagi mengikut peraturan Ketinggian lompatan di ukur secara menegak dari aras tanah hingga bahagian tengah disebelah atas padang. Setiap peserta akan diberi peluang sebanyak tiga kali untuk melakukan lompatan. Jika peserta tidak berhasil melewati mistar sebanyak tiga kali berturut-turut, dia dinyatakan gagal. Untuk menentukan kemenangan, para peserta harus berusaha melompat setinggi mungkin yang dapat dilakukan. Pemenang ditentukan dengan lompatan tertinggi yang dilewati. 


\section{Upaya}

Gaya ini ditemukan oleh Sweney, oleh karena itu juga sering disebut dengan

Gaya Sweney. Sebelumnya di tahun 1880, Sweney menggunakan gaya jongkok, namun ia merasa gaya tersebut kurang tepat hingga akhirnya beliau mengubah gaya tersebut menjadi gaya gunting pada tahun 1896. Gaya gunting atau gaya Swenney. Terjadi pada tahun 1880 - permulaan abad ke 20. maka antara tahun 1896 swenny mengubahnya dari gaya jongkok itu menjadi gaya gunting. Karena gaya jongkok kurang ekonomis. Cara melakukan gaya gunting adalah mula-mula pelompat mengambil awalan dari tengah. Bila pelompat pada saat akan melompat menggunakan kaki kiri sebagai tumpuan lalu memakai kaki kanan sebagai ayunan, maka ia mendarat (jatuh) dengan kaki kanan juga.

Gaya ini banyak dianggap gaya paling mudah dilakukan karena gerakan dan gaya di udara dan akhiran nya dengan kaki terkuat. Mengapa dinamakan gaya gunting? Alasannya karena posisi kaki yang melakukan tolakan, mengayun dan akhirnya kedua kaki serta seluruh tubuh melewati mistar nampak seperti gerakan gunting. Nah, tahapannya seperti apa? Kalian dapat penjelasannya berikut ini.

\section{Awalan}

Gerakan awalan bagi atlet dapat dilakukan dengan cara berlari dari arah depan dan agak serong ke arah kanan ataupun kiri. Hal itu disesuaikan keinginan dari atlet sendiri baik dalam menggunakan kaki untuk tumpuan maupun arah ia akan berlari.

Jadi, jika menggunakan tumpuan kaki kanan, maka awalan dilakukan dari samping kanan. Akan tetapi, jika tolakannya menggunakan kaki kiri maka awalan dilakukan dari samping kiri juga.

Hal yang perlu diingat ketika mengambil posisi ancang-ancang, usahakan tidak terlalu jauh setidaknya 3 sampai 9 langkah menyesuaikan dengan tinggi mistar. Selain itu, ambillah posisi awalan setidaknya 30-40 derajat dari tiang ataupun mistar. 


\section{Tumpuan}

Kalian bebas memilih kaki mana yang akan digunakan sebagai tumpuan, sebaiknya sesuai kenyamanan agar melompati mistar lebih mudah. Akan tetapi, usahakan menggunakan kaki terjauh dari tiang mistar. Nah, pada saat melakukan tolakan posisi badan agak telungkup dan agak condong ke belakang.

Selanjutnya, kaki yang tidak digunakan untuk tumpuan harus mengayunkan kaki tersebut lurus kedepan dan kearah atas menyilang dari tiang mistar.

\section{Saat Melayang}

Pada tahap ini, kaki yang digunakan tumpuan diayunkan lurus kearah samping kanan atau kiri (sesuai posisi tubuh atlet) sampai ketinggian maksimum. Sedangkan, kaki yang bebas tumpuan diayunkan lurus ke arah belakang sehingga terlihat seperti gunting melewati mistar.

Lalu segera diikuti badan diputar ke kanan atau kiri. Usahakan pandangan tidak ke bawah dan mengarah pada tempat pendaratan karena akan mengganggu konsentrasi. Nah, ketika posisi tubuh sudah mulai turun kaki segera diluruskan.

\section{Pendaratan}

Tahapan terakhir ialah pendaratan, pastikan posisi badan kalian tetap rileks dan tidak terlalu tergesa-gesa mendarat. Ketika pendaratan, usahakan kaki belakang diangkat setinggi mungkin agar tidak mengenai mistar. Saat kaki diayun dan menurun melewati mistar dan posisi badan hampir tegak serta kondisi mistar dibawah panggul. Saat itulah, kaki melakukan tolakan untuk mendarat dengan badan menghadap ke samping.

Dibalik kelebihan gaya gunting ini, terdapat juga kelemahan gaya ini. Beberapa kelemahan gaya gunting.

- Titik tumpu jauh dari mistar.

- Saat posisi melayang melewati mistar, memerlukan banyak tenaga sehingga kurang efisien.

- Saat melayang melewati mistar, jarak antara titik berat badan dengan mistar terlalu jauh. 
Ada beberapa hal yang patut diperhatikan oleh pelompat guna mencapai hasil yang maksimal (lompatan tertinggi).

\section{Beberapa hal yang perlu dihindari antara lain sebagai berikut.}

1. Lari awalan yang terlalu cepat

2. Meluruskan kaki penolak terlalu jauh kedepan.

3. Gerak kombinasi kaki yang tidak sempurna.

4. Badan condong mendekati mistar.

5. Posisi tangan pada mistar terlalu tinggi.

6. Melewati mistar dalam posisi duduk.

7. Membuat lengkung badan terlalu awal.

8. Gerak terlambat dari gaerk angkat kaki akhir.

\section{Sedangkan berapa hal yang perlu diutamakan oleh pelompat adalah sebagai berikut.}

1. Lari awalan dengan kecepatan yang terkontrol.

2. Menghindari kecondongan tubuh ke belakang terlalu banyak.

3. Mencapai gerakan yang cepat pada saat bertolak dan mendekati mistar.

4. Mengusahakan angkat vertikal pada saat take off atau pada saat kaki bertolak meninggalkan tanah.

5. Mendorong bahu dan lengan ke atas pada saat take off.

6. Melengkungkan punggung di atas mistar.

7. Mengusahakan mengangkat sempurna dengan putaran ke dalam dari ayunan lutut.

8. Mengangkat kemudian meluruskan kaki segera sesudah membuat lengkungan. 


\section{Pendukung Efektivitas}

Capaian prestasi membuat suatu orang merasa bahagia denagn bisa mendapat juara. Seseorang berprestasi dalam lompat jauh ini pasti mewakili nama sekolah, wilayah, bahkan Negara. Beberapa capaian prestasi suatu wilayah, Negara didukung oleh sarana dan prasarananya yang memadai. Meski tidak sedikit dana yang digelontorkan demi membahagiakan pencinta lompat tinggi dan bahkan punya ekspetasi yang bisa dijadikan realita membuat catatan prestasi yang bagus di kancah Internasional. Impact atau Dampak dari fasilitas adalah menghasilkan prestasi dan sumber dana karena sekarang olahragawan banyak menghasilkan uang dari bakatnya, termasuk dari lompat tinggi. Di acara atletik lompat tinggi juga banyak disorot dan banyak dilihat dan didukung.

\section{Sarana dan Prasarana Lompat Tinggi}

\section{Tiang dan Mistar Lompat}

Tiang dan mistar yang digunakan dalam permainan lompat tinggi harus memenuhi beberapa ketentuan. Semua bentuk dan model tiang lompat dapat digunakan asalkan kaku dan kekar. Tiang memiliki penopang yang kaku dan kokoh untuk mistar, serta haruslah cukup tinggi untuk melebihi tiang sebenarnya terhadap mana mistar lompat dinaikkan dengan minimum $10 \mathrm{~cm}$. Jarak antara tiang lompat harus tidak kurang dari $4 \mathrm{~m}$ juga tidak melebihi dari 4,04 m. Tiang lompat/tiang harus tidak dipindah selama perlombaan berlangsung kecuali bila wasit memikirkan bahwa apakah tempat bertumpu atau pendaratan menjadi tidak sesuai lagi.

Mistar dapat dibuat dari metal atau kayu, berbentuk bulat atau segitiga dengan diameter minimum 2,5 $\mathrm{cm}$ dan maksimum $3 \mathrm{~cm}$, dengan permukaan yang datar atau rata pada kedua ujung yang berguna untuk meletakkan pada papan penopang. Panjang mistar minimal 3,64 m dan maksimal $4 \mathrm{~m}$, berat maksimal $2 \mathrm{~kg}$. Mistar lompat harus terbuat dari fiberglass atau materi atau bahan lain yang cocok namu bukan dari metal, bagian tengahnya/potongan melintangnya bulat silindris kecuali pada kedua ujung mistar. Garis tengah/diameter pada bagian mistar yang bulat silindris haruslah 30mm. Ujung mistar lompat harus terletak di atas sedemikian rupa sehingga bila mistar disentuh oleh pelompat akan dengan mudah jatuh ke tanah, baik di depan maupun di belakang. 


\section{Matras (Tempat Pendaratan)}

Tempat pendaratan lompat tinggi harus memenuhi ketentuan, yakni tidak boleh kurang dari 3 x $5 \mathrm{~m}$ yang terbuat dari busa dengan ketinggian $60 \mathrm{~cm}$ dan di atasnya ditutupi oleh matras yang tebalnya $10-20 \mathrm{~cm}$ dengan warna terserah.

\section{Lapangan Lompat Tinggi}

Lapangan lompat tinggi terdiri atas tiga bagian, yakni jalur ancang-ancang, tempat/area bertolak, dan tempat pendaratan. Daerah awalan (jalur ancang-ancang) panjangnya tidak terbatas dengan minimum $15 \mathrm{~m}$, daerah tumpuan (tempat bertolak) harus datar dan tingkat kemiringanya $1: 100$, sedangkan tempat pendaratan harus dilengkapi dengan matras agar pelompat tidak cedera.

Setelah kita mendapat fasilitas dengan sarana dan prasarana yang mempuni dan lengkap selengkap-lengkapnya. Dalam mengurus dan menjaga fasilitas itu haruslah punya penjaga dan petugas kebersihan, serta kebersihannya harus dijaga oleh setiap orang yang telah memakai fasilitas itu, karena buat apa dibangun tapi yang memakainya tidak menjaga. Di Indonesia penjagaan fasilitas ini harus diterapkan, bukan hanya diterapkan tetapi dirawat bila ada yang rusak diganti secepatnya, bila ada yang berkarat di cat, dan sebagainya agar bisa dipakai sampai kegenerasi selanjutnya dengan aman dan terawat dengan baik.

Di Indonesia sendiri fasilitas lompat tinggi di setiap daerah sangat sedikit dan tidak memadai. Hampir setiap daerah hanya memiliki satu gedung tempat untuk melakukan lompat tinggi atau bahkan ada daerah yang sama sekali tidak memiliki fasilitas untuk melakukan aktifitas lompat tinggi. Tidak semua orangtua paham bahwa olahraga lompat tinggi kategori atletik ini banyak digandrungi, tidak sedikit juga orangtua yang beranggapan bahwa jika anaknya punya bakat ini, anaknya tidak dapat apa-apa hanya rasa lelah. Kurangnya kompetisi di usia muda dan kurangnya fasilitas di setiap daerah punya andil berkurangnya bibit-bibit unggul yang bisa berprestasi. Indonesia hanya mengendalkan orang yang bisa menghasilkan prestasi di ajang sebelumnya dan terus mengandalkannya tanpa ada pencarian dan peningkatan sarana dan prasarana 


\section{Ekspetasi, Harapan, dan Kesimpulan}

Kita bisa beranggapan bahwa dengan berjuta-juta penduduk di Indonesia, kita pasti punya segudang bibit-bibit muda yang berbakat, tetapi dengan kepulauan yang luas setiap pelatih jarang ingin mencari bibit muda kepelosok-pelosok. Ada yang beranggapan atlet yang berprestasi hanya itu saja tidak pernah berubah. Bukan karena tidak ada atlet yang bagus, keterbatasan akses ke pelosok menjadi alasan. Ada yang bisa tetapi tidak punya pelatih, ada yang niat tapi tidak tahu dari mana.

Efektivitas bisa membangun fondasi agar selalu adanya bibit mudah, mengatasi keterbatasan sarana dan prasarana dengan memberi dana ke Departemen Olahraga dan Kebudayaan daerah di Indonesia agar dapat membantu pembangunan gedung olahraga cabang lompat tinggi ini. Pemerintah harus memperhatikan setiap atlet juga dalam pelatnas agar prestasi tetap terjaga dan menjaga sportifitas dalam bertanding. Pembimbingan pelatih harus juga dilakukan guna mendapatkan bibit muda hasil latihan sang pelatih. Jika pelatih bisa melatih dengan baik meski dengan minim pengalaman tidak usah khawatir karena kita sedang membangun dan berharap anak didiknya harus bisa melebihi kita dan dia bisa menjadi pelatih dan memotivasi generasi berikutnya.

Tujuan dari lompat tinggi agar dapat mencapai lompatan yang setinggi - tingginya. Lompat tinggi tidak susah melakukannya tetapi butuh keberanian dalam melakukannya. Saat ini Indonesia butuh bibit muda agar dapat berprestasi. Tidak susah melakukan lompat tinggi apalagi dengan gaya gunting (scissors). Kita harus mengetahui peraturannya agar kita tidak salah dalam melakukannnya. Dan harus adanya bimbingan agar dapat melakukan lompat tinggi gaya gunting dengan baik. Peningkatan dari semua aspek pembangunan untuk kemajuan prestasi olahraga lompat jauh adalah bukti efektivitas. Kita ingin prestasi maka kita harus berani mengambil keputusan dengan baik. 


\section{Daftar Pustaka}

http://zuliaden-jayus.blogspot.com/2014/08/makalah-lompat-tinggi.html

https://vita-project.blogspot.com/2018/05/makalah-lompat-tinggi.html

http://niikenrahmayanti.blogspot.com/2014/11/makalah-olahraga-lompat-tinggi-dan.html

https://aturanpermainan.blogspot.com/2016/04/teknik-lompat-tinggi-gaya-gunting-scissors.html

https://id.wikipedia.org/wiki/Lompat_tinggi

https://brainly.co.id/tugas/22952852

file:///C:/Users/user/Downloads/Peningkatan_hasil_belajar_lompat_jauh_gaya_jongkok.pdf

https://www.google.com/search?q=makalah+tenteng+lompat+tinggi\&oq=makalah+tenteng+lompat+tin ggi\&aqs=chrome..69i57.7026j0j1\&sourceid=chrome\&ie=UTF-8 